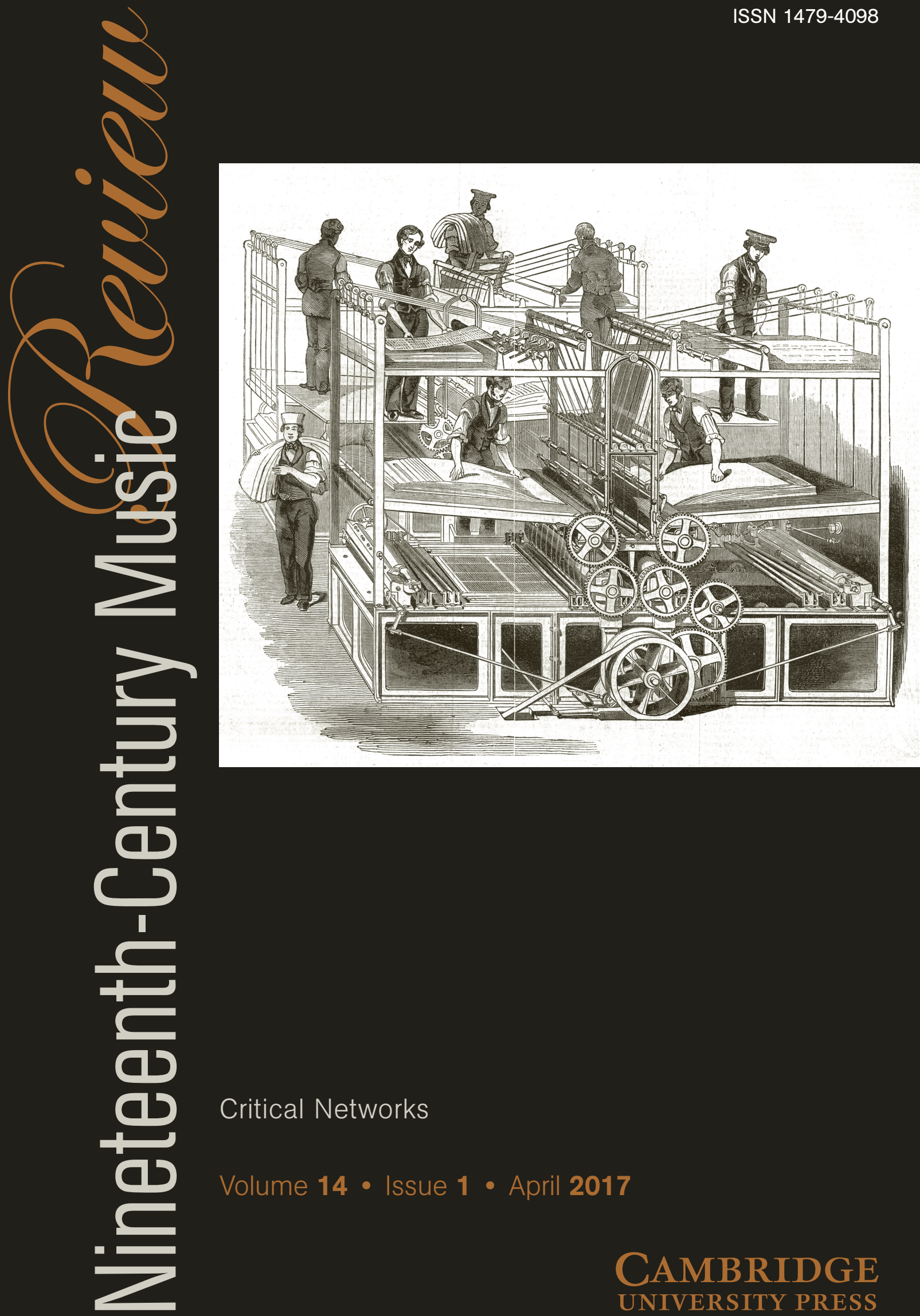




\section{Nineteenth-Century Music Review}

Nineteenth-Century Music Review locates music within all aspects of culture in the long nineteenth century, covering the widest possible range of methods, topics and concepts. Articles provide both depth and breadth in their contribution to this expanding field. A rich supply of book, CD, DVD and score reviews reflects the journal's commitment to stimulate and advance critical discussion.

\section{General Editor}

BENNETT ZON, Durham University, UK

\section{Editorial Board}

ANDREAS GIGER

Louisiana State University, USA

BLAKE HOWE (CD/DVD Review Editor)

Louisiana State University, USA

BENJAMIN M. KORSTVEDT (Score Review Editor)

Clark University, USA

PHILIP V. BOHLMAN

University of Chicago, USA

ANDREW BOWIE

Royal Holloway, University of London, UK

SUSANNAH CLARK

Harvard University

NICHOLAS COOK

University of Cambridge, UK

JOHN DEATHRIDGE

King's College, University of London, UK

JAMES DEAVILLE

Carleton University, Canada

JEREMY DIBBLE

Durham University, UK

STEPHEN DOWNES

Royal Holloway, University of London, UK

KATHARINE ELLIS

Bristol University, UK

ANNEGRET FAUSER

University of North Carolina, Chapel Hill, USA

PETER FRANKLIN

University of Oxford, UK

SOPHIE FULLER

Trinity College of Music, UK

LYDIA GOEHR

Columbia University, USA

THOMAS GREY

Stanford University, USA
HEATHER PLATT (Digital Review Editor)

Ball State University, USA

JAMES WILLIAM SOBASKIE (Book Review Editor)

Mississippi State University, USA

WILLIAM WEBER

California State University, Long Beach, USA

\section{Advisory Board}

SARAH HIBBERD

University of Nottingham

JULIAN HORTON

Durham University, UK

LINDA HUTCHEON

University of Toronto, Canada

ALICIA LEVIN

University of Kansas

RALPH LOCKE

Eastman School of Music, USA

ROBERTA MARVIN

University of lowa, USA

SIMON McVEIGH

Goldsmiths College, University of London, UK

JULIAN RUSHTON

University of Leeds, UK

DOUGLASS SEATON

Florida State University

MARY ANN SMART

University of California, Berkeley, USA

NICHOLAS TEMPERLEY

University of Illinois, USA

SUSAN WOLLENBERG

University of Oxford, UK

SUSAN YOUENS

University of Notre Dame, USA

SUBSCRIPTIONS Nineteenth-Century Music Review (ISSN 1479-4098) is published three times a year in April, August and December. Three parts form a volume. The subscription price (excluding VAT) of volume 14 (2017), which includes print and electronic access, is $£ 214$ net (US\$340 in the USA, Canada and Mexico) for institutions; and £42 net (US\$69 in the USA, Canada and Mexico) for individuals, ordering direct from the publisher and certifying that the journal is for their personal use. Single parts are $£ 82$ (US\$130 in the USA, Canada and Mexico) plus postage. EU subscribers (outside the UK) who are not registered for VAT should add VAT at their country's rate. VAT-registered customers should provide their VAT registration number. Japanese prices for institutions (including ASP delivery) are available from Kinokuniya Company Ltd., P.O. Box 55, Chitose, Tokyo 156, Japan. Prices include delivery by air where appropriate.

Orders, which must be accompanied by payment, may be sent to a bookseller, subscription agent or direct to the publisher: Cambridge University Press, Journals Fulfilment Department, UPH, Shaftesbury Road, Cambridge CB2 8BS, UK; or in the USA, Canada and Mexico: Cambridge University Press, Journals Fulfillment Department, 1 Liberty Plaza, Floor 20, New York, NY 10006, USA.

COPYING This journal is registered with the Copyright Clearance Center, 222 Rosewood Drive, Danvers, MA 01923, USA. Organisations in the USA who are registered with C.C.C. may therefore copy material (beyond the limits permitted by sections 107 and 108 of U.S. Copyright law) subject to payment to C.C.C. of the per copy fee of $\$ 12$. This consent does not extend to multiple copying for promotional or commercial purposes. Code 1479-4098/2017. ISI Tear Sheet Service, 3501 Market Street, Philadelphia, PA 19104, USA, is authorised to supply single copies of separate articles for private use only. Organisations authorised by the Copyright Licensing Agency may also copy material subject to the usual conditions. For all other use, permission should be sought from Cambridge or from the North American Branch of Cambridge University Press.

This journal is included in the Cambridge Core service which can be found at cambridge.org/core.

(C) Cambridge University Press 2017 


\section{Contents}

\section{VOLUME 14, ISSUE 1}

Notes on Article Contributors

\section{ARTICLES}

Paul Watt and Sarah Collins

Critical Networks

Michel Duchesneau

French Music Criticism and Musicology at the Turn of the Twentieth

Century: New Journals, New Networks

\section{Paul Watt}

Musical and Literary Networks in the Weekly Critical Review, Paris,

1903-1904

Noel Verzosa

Realism, Idealism and the French Reception of Hanslick

Sarah Collins

Nationalisms, Modernisms and Masculinities: Strategies of Displacement in Vaughan Williams's Reading of Walt Whitman

Holly Watkins

Toward a Post-Humanist Organicism

\section{Book Reviews}

\section{William Weber}

Archives du concert: La vie musicale française à la lumière de sources inédites by Étienne Jardin and Patrick Taïeb

Mary Sue Morrow

Two Centuries of British Symphonism from the Beginnings to 1945:

A Preliminary Survey by Jürgen Schaarwächter

Anna Stoll Knecht

Gustav Mahler's Symphonic Landscapes by Thomas Peattie

Mahler's Symphonic Sonatas by Seth Monahan

\section{REVIEWS}

Clive Brown

Re-sound Beethoven, Orchester Wiener Akademie, Martin Haselböck cond Alpha 470, 2015 (1 CD: 57 minutes) 
Douglas Shadle

George Frederick Bristow, Symphony No. 2 ('Jullien'); Overtures,

Royal Northern Sinfonia, Rebecca Miller cond New World Records

80768-2, 2015 (1 CD: 61 minutes); and Dvoř́k and America,

Naxos 8.559777, 2014 (1 CD: 76 minutes)

\title{
DVD REVIEWS
}

Katherine Syer

Richard Wagner, Der Frankfurter Ring: Der Ring des Nibelungen,

Frankfurter Opern- und Museumsorchester, Sebastian Weigle, cond, Vera Nemirova, stage director, Oehms Classics 999 (8 DVDs: 941 minutes)

Lisa Feurzeig

Franz Schubert, Fierrabras, Vienna Philharmonic, Ingo Metzmacher cond,

Peter Stein stage director, C Major 730708, 2014-15 (2 DVDs: 164 minutes [opera] and 10 minutes [bonus material])

\section{SCORE REVIEW}

\section{Katharina Uhde}

Niccolò Paganini, 24 Capricci per Violino solo op. 1; 24 Contradanze Inglesi per Violino solo edited by Daniela Macchione. Bärenreiter-Verlag Urtext.

Kassel: Bärenreiter-Verlag Karl Vötterle GmbH und Co. KG, 2013.

xviii + 58 pp., violin part BA 9424, €16,95

\section{Review Article}

\author{
Alison Hood \\ Chopin Online
}

